\title{
Monetary policies and financial crisis: Towards a new central banking
}

Comment on "An evaluation of the effects of unconventional monetary policies on the cost of credit to companies in the eurozone" by Désiré Kanga and Grégory Levieuge, "Monetary policy, illiquid collateral and credit in the economy during the European sovereign debt crisis" by Jean Barthélémy, Vincent Bignon and Benoît Nguyen, and "Can better capitalised banks be more profitable? An analysis of large French banking groups before and after the financial crisis" by Olivier De Bandt, Boubacar Camara, Pierre Pessarossi and Martin Rose.

\section{André Cartapanis*}

\begin{abstract}
Three articles of this special issue evaluate the effects of unconventional monetary policies and the relationships between new capital requirements and bank profitability. These articles present several similarities: two of them draw on individual bank data and not on aggregated data; they highlight the combined consequences of several shocks, by introducing an interaction term between several variables; they conclude to a strong heterogeneity or a heightened magnitude of the effects brought on credit or bank profitability. That comment will underline that if policies of liquidity injections at a time of stress are especially efficient as they draw on widened collaterals, then it is important to keep certain unconventional instruments in the central banks' toolbox, including outside times of crisis. And if the transmission channels from these policies to lending rates demand close coordination with the fixing of short term interest rates and turn out to have heterogeneous effects due to each banking intermediary's specific situation, then rates policy must be closely correlated to both microprudential and macroprudential policies.
\end{abstract}

JEL Classification: E52, E58, G01, G21, G28

Keywords: monetary policy, central bank, credit, financial crisis, bank capital, prudential regulation

Reminder:

The opinions and analyses in this article

are those of the author(s)

and do not

necessarily reflect

their institution's

or Insee's views. 
The financial crisis has led to extensive changes to central banking. By leading central banks to urgently manage, firstly, the liquidity crisis coming from the American banking system, then the banking crisis and the sovereign debt crisis in the eurozone, this crisis brought about a reconfiguration of both monetary policies and prudential regulations. Of course, this was in the form of short term interest rates near to zero. But also by conducting unconventional policies that, at the outset, amounted to a leap into the unknown (Rajan, 2013). Finally, the deepening of microprudential and macroprudential rules, within the framework of Basel III, brings out the new role granted to the preservation of financial stability, as well as monetary stability, among the objectives assigned to the central banks and supervisors, notably by raising capital requirements for banks.

While the normalisation of monetary policies is now topical (BIS, 2017), this experience of unconventional policies and the first steps taken in the reconfiguration of prudential policies are far from having led to a new consensus about the transmission channels taken by these new instruments or about their real and financial effects. The three contributions covered in this issue dedicated to "The crisis, 10 years after" bring original responses to several of these interrogations: with regards to the effects of unconventional monetary policies on the cost of credit in the eurozone; regarding the efficiency of the unconventional provision of liquidity against collaterals to banks in the eurozone; and, finally, regarding the relationships between capital requirements imposed on banks and their profitability.

After a few comments on the specific lessons to be learned from these three contributions, we will widen this analysis to the outlines, still uncertain, of the new post-crisis central banking.

\section{The question of the effects of unconventional monetary policies in the eurozone}

Unconventional monetary policies target several objectives and involve different types of instruments face to face the risk of ineffectiveness of the conventional action on short term interest rates in times of crisis. The objectives are: to support banks facing a liquidity run; the better transmission of the interest rates policy towards the cost of credit and its volume; the direct influence on long term interest rates because of increased risk premiums. The instruments are: massive liquidity injections to banks, coupled with the redefinition of eligible collaterals or the extension of maturities; the practice of zero rates and of negative base rates; forward guidance of rates expectations... The purpose is therefore, in times of crisis, to both ensure the solvency of banking establishments in difficulty and to oppose a large-scale credit crunch which would be of such a nature as to provoke a strong contraction of economic activity. For the eurozone, notably between 2011 and 2014, it was more specifically a matter of controlling the contagion of illiquidity to which the European banks were subjected with the sovereign debt crisis and, also, to stem the rise of risk premiums and the climb of long term rates despite short term interest rates being close to zero.

With this backdrop, the article by Désiré Kanga and Grégory Levieuge examines the repercussions of the ECB's unconventional policies on the cost of credit for non-financial companies, between 2003 and 2014, with particular attention to the years 2008-2014. Their contribution, which draws on aggregated individual bank data over monthly periods for 11 eurozone countries, presents several original ideas in methodological terms: the splitting up of different forms of liquidity injections (fixed-rate full allocations, widening of the range of eligible collaterals, extension of the maximum maturity of refinancing operations...) and the consideration of different asset purchase programmes; for each measure, a distinction is made between the direct effects and indirect effects by way of an interaction term with the interbank market interest rate; and for the period September 2008-December 2014, they use a panel conditionally homogeneous VAR (PCHVAR) model to explain the heterogeneity of the impact of unconventional policies depending on the macroeconomic, financial or banking particularities of the economies concerned. Without going into the details of the results, two major phenomena are highlighted: on the one hand, the indirect effects on the lowering of base rates, that being the effects conditional to rates policy, are much more significant than the direct effects, with a more pronounced influence of the widening of guarantee conditions on collaterals; on the other hand, we observe a strong heterogeneity of this impact on the cost of credit depending on the unconventional instruments mobilised (with a dominant factor for fixed-rate liquidity allocations and long term refinancing operations, LTRO and TLTRO), depending on the country (a higher impact in Austria, Germany, Spain and 
Italy, and a negligible or insignificant impact in France, Greece and Ireland) and according to the macroeconomic or macro-financial characteristics of each country. The impact of the lowering of rates on the cost of credit is especially weak given that growth is declining, that systemic risk is high, that bank ratios have declined and that the public debt to GDP ratio is strongly increasing. To sum up, unconventional monetary policies led by the ECB are moderately efficient in terms of lowering the cost of credit, and they operate mainly through indirect effects backed with the traditional transmission channels of rates policy. But the impact is highly heterogeneous and it is not the countries which needed them the most, faced with the extent of the credit crunch risk, who benefited from them the most. We will soon come back to the lessons that can be learned in terms of new central banking.

Again for the eurozone, Jean Barthélémy, Vincent Bignon and Benoît Nguyen study another aspect of unconventional policies, this time the impact, not on rates but on credit volume, of the emergency rescue operations led by the ECB among banks during the sovereign debt crisis between January 2011 and December 2014. At that time, with growing interbank market illiquidity, the European authorities not only considerably increased their liquidity injections, but also widened the range of collaterals accepted for this purpose, notably for non-negotiable assets on interbank markets, labelled as illiquid, like the debts arising from non-securitised credit granted, all the while presenting a risk of default lower than $0.4 \%$, and even ranging temporarily from $0.4 \%$ to $1.5 \%$. Available since 2007, it is from 2009 and at the time of the sovereign debt crisis that the central banks members of the ESCB (European System of Central Banks) widely accepted these collaterals in return for liquidity injections to eurozone banks. By using monthly individual data on the largest 177 banks in the eurozone (refinancing volumes granted, composition of the pool of collaterals provided, balance sheets), the authors first build, in a highly original way, an individual indicator of bank run (identified when interbank financings decline by at least $10 \%$ from one month to the next, and measured in volume and duration) that is, an indicator of rationing of the refinancing obtained in euros on the European interbank market or in dollars on the American Money Market Mutual Funds market, in order to match this indicator on the one hand with the amount of illiquid collaterals having enabled each bank concerned access to the unconventional liquidity injections, and on the other hand to the evolution of credit granted to non-financial companies and households. In other words, it is a matter of examining the last resort lending role of the ECB to banks suffering a run on the interbank market, not from the point of view of rescuing banks, but in light of the effects on credit granted to the real economy. Panel regression, with a fixed effect by bank and by country, provides very clear results: it is the banks which provided the most, proportionately, of their illiquid collaterals to the ECB which reduced the least, or increased the most, their credit to companies and households a month later, all throughout the eurozone crisis. This is a mark of success for the ECB, with the increase of last resort loans and the widening of eligible collaterals having limited the extent of the credit crunch connected to the sovereign debt crisis, while more than $40 \%$ of the sample of banks considered were faced with a run over the summer of 2011. Again, we will come back to the lessons that can be learned with regard to the normalisation of policies conferred to the central banks.

\section{Ratios of capital and bank profitability}

The contribution from Olivier de Bandt, Boubacar Camara, Pierre Pessarossi and Martin Rose does not directly address questions of unconventional monetary policy but rather the challenges brought on by the new prudential regulations since the crisis. We know the Basel III objectives, whose implementation is incomplete: improve the volume and quality of capital in order for banks to be better able to resist an unanticipated drop in the value of their assets; prevent situations of illiquidity by limiting maturity transformation and recourse to short term interbank financings, through the creation of two new liquidity ratios; take better account of exposures to counterparty default risks on derivatives, reverse repurchase agreements, securities loans and the development of off-balance sheet securitisation structures; complement risk weighted capital requirements, like in Pillar I of Basel II, by another device, the leverage ratio; and implement countercyclical capital buffers at the discretion of the supervisors. Yet the quantitative raising of capital requirements, but also their enhanced quality, with a higher proportion of ordinary shares, have worried banks, invoking a threat to their profitability, on the cost and volume of credit, indeed on economic growth. Hence the question raised in this article: beyond the positive effects on banks' resilience to illiquidity shocks or major defaults, does capitalisation negatively affect bank profitability? 
The analysis, mainly econometric, is conducted over the period 1993-2012 based on a sample of 17 French banking groups among the largest. Whatever the measures of capitalisation, including on the basis of the Basel III ratios, the leverage ratio in particular, the panel model estimated, with fixed effects, confirms what some BIS analyses (Borio, 2016b) had already highlighted without offering an empirical demonstration: beyond the tendential downward evolution of bank profitability over the course of this period, the banks whose capital ratios increase more than the average register a relative rise in their profitability, of course after having taking into account a whole series of control variables. Reference is made to the article for the details of the results, but two observations must be formulated: on the one hand, the positive effect is much higher on the return on assets (ROA) than on the return on equity (ROE); on the other hand, the range of influence is very wide since in response to an increase of 100 basis points of one of the capitalisation ratios, the positive effect on profitability varies from 3 to $10 \%$ for ROE and 7 to $30 \%$ for ROA. The originality and robustness of the method of measuring bank capitalisation should be noted. Firstly, this is because Olivier de Bandt, Boubacar Camara, Pierre Pessarossi and Martin Rose use confidential data provided by the French Prudential Supervision and Resolution Authority; these data include not only regulatory capital but also data on the extra capital requirements in accordance with Pillar II imposed on each bank at the initiative of the supervisor, without this being made public, ensuring a measure which is much closer to the reality of each bank's capitalisation. Then, it is because the sample includes very contrasting business models (on average, loan share represents $28 \%$ of the balance sheet for the first decile and $88 \%$ for the last decile), and the tests do not allow to differentiate the results according to the traditional opposition between retail banks and investment banks. It is also due to the estimations explaining this positive relationship between capitalisation and profitability: a positive link between capitalisation on the one hand and the weight of loans to households and companies or the improvement to banks' efficiency (measured using the net operating surplus ratio over administrative expenses) on the other hand. Finally, it is because the estimation period is long enough to include several business cycles, with successive regimes of more or less high interest rates, between 1993 and 2012. In other words, the reinforcement of capital that French banks, to different extents, have been held to honour or that they have decided to implement, seems in no way to negatively affect their profitability and therefore would not call into question the new Basel III options.

\section{Normalisation or reconfiguration of central banking?}

Beyond the results treating specifically each of the research targets chosen (the cost and volume of credit in the eurozone, bank profitability in France) in response to regulatory or policy changes linked to the financial crisis, these articles present several particularities: two of them draw on individual data (bank or financial data by country) and not on aggregated data to analyse banking behaviour; by introducing an interaction term between several explanatory variables, they highlight the combined effects of several shocks; beyond the parameters estimated, they conclude with a strong heterogeneity or a high magnitude of induced effects on credit supply or banks' profitability. Yet there are lessons to be learned here from the point of view of post-crisis central banking.

The discussions are numerous about the normalisation of monetary policies. Despite the slight increase of rates in the US, it is not certain that we have already entered a conventional monetary regime that significantly distances us from zero rates. For Summers (2015), the increase in inequalities, and population ageing, would push desired savings rates up and lead to a decline of the natural interest rate, that is the rate ensuring a full-employment macroeconomic equilibrium. If we add the deceleration of the productivity gains and the slowdown of potential supply growth (Gordon, 2015), we find here the issue of secular stagnation whose prominent symptom is the weakness, even negative level, of the post-crisis natural interest rate. With a backdrop of short term interest rates nearing zero and inflation much lower than the central banks' targets, around $2 \%$, it is not certain that the rise in rates will be confirmed. Unconventional monetary policies could therefore remain necessary, despite the fact that financial tensions seem to be reappearing on stock markets and real estate prices.

From the point of view of post-crisis central banking, the paradigm associating monetary targeting only with the adjustment of short term interest rates, while retaining the principle of separation between the objectives of monetary stability and financial stability, and validating the dominant microprudential factor of bank 
regulation... all this seems to be behind us, without a new model having been imposed yet. This is especially so since the recourse to unconventional monetary policies has accentuated this difficulty by raising new questions, firstly of an operational nature. Must we go back to the only rates policy by adjudication on a pro rata basis of the liquidity requests or must we keep using the fixed-rate full allocation method? Must we keep making direct interventions on medium or long term rates (as with LTRO and TLTRO) in the eurozone? Must accepting illiquid collaterals be reserved for last resort loans? How far must the quantification of forward guidance go? Beyond these technical questions, the interrogations on the new central banking also show a more fundamental nature. How must the policy of price stability and the banking system's objective of financial stability now be articulated? Two models are worth consideration (Betbèze et al, 2011): A strict separation of the two objectives by assigning to them dedicated instruments which two distinct institutions would have, the central bank and the supervisor, while respecting the Tinbergen rule? Or a more integrated model in the hands of a central bank equipped with multiple functions, for example by adding a module of bank crisis risk into the central bank's reaction function via short term rates, drawing on the consideration of the financial cycle (Borio, 2016a)? Or yet still by placing multiple instruments under its sole responsibility, from rates policy to macroprudential policy, last resort interventions on microprudential policies, from quantitative easing in times of crisis to forward guidance, as has already been rolled out since 2014 with the implementation of the ECB's sole banking supervision within the framework of the European Banking Union? Beyond governance, it is the outlines of the mandate given to the monetary authorities which are at stake, and also indirectly the question of the central bank's independence, especially in times of crisis.

Answering these questions is not the point of this comment. This must not prevent us from noting that the debates relating to the new central banking are addressed, in the literature but also among the central bankers, from a specifically macroeconomic perspective, in reference to the optimality of the decisions of one or several public institutions, the central bank and/or the supervisor, faced with a representative agent presumed to be homogeneous, the banks or the banking system, ensuring the transmission of monetary shocks or regulatory innovations towards the real economy or financial markets. These analyses of central banking rarely come from a microeconomic perspective which integrates the heterogeneity of banking intermediaries or the combined effects and the interactions of changes to several instruments, in a macro-financial climate which greatly restricts each bank's reactions. Yet, the results presented in the three articles to which this comment is dedicated may also provide valuable contributions to the debates on the new central banking.

If the policies of liquidity injections in times of stress are especially effective in avoiding a credit crunch since they draw on widened collaterals, then it is important to maintain certain unconventional instruments in the central banks' toolbox, and also to mobilise them outside of crises. It is therefore important to avoid that normalisation lead to give them up. If the transmission channels of these policies towards lending rates demand close coordination with the fixing of base rates and turn out to be heterogeneous due to the specific situation of each bank (weight of non-performing loans, capital ratios, liquidity ratios, bank profitability) then, to be effective, the rates policy must be closely correlated to both microprudential policies (extra capital in accordance with Pillar II) and macroprudential policies (changes to the countercyclical capital buffer). This is especially so when the concentration of the banking sector multiplies interdependencies between the microprudential and macroprudential, which is the case in the eurozone (Panetta, 2016; Alessandri \& Panetta, 2015).

We believe that the new central banking must operate via an enhanced granularity of monetary and financial regulations managed by one sole institution leading discretionary policies aiming at objectives of both monetary and financial stability, without any obligation to satisfy a defined ex ante decision-making rule (Santor \& Suchanek, 2016). It must also operate by mobilising the full range of monetary and regulatory measures used during the financial crisis. In a way, by making the unconventional policies conferred to central banks durable in the post-crisis period. 


\section{BIBLIOGRAPHY}

Alessandri P. \& Panetta F. (2015). Prudential Policy at Times of Stagnation: a View from the Trenches. Bank of Italy Occasional Papers $N^{\circ} 300$.

Betbèze J.-P., Bordes C., Couppey-Soubeyran J. \& Plihon D. (2011). Banques centrales et stabilité financière. Paris : Conseil d'Analyse Economique.

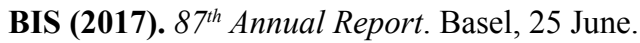

Borio C. (2016a). Towards a Financial Stability-Oriented Monetary Policy Framework. Conference on the Occasion of the $200^{\text {th }}$ Anniversary of the Central Bank of Austria, 13-14 September.

Borio C. (2016b). The Banking Industry: Struggling to Move on. Firth EBA Research Workshop, London, 28-29 November.
Gordon R. (2015). Secular Stagnation: A SupplySide View. American Economic Review, 105(5), 54-59.

Panetta F. (2016). Central Banking in the XXI Century: Never Say Never. Baffi-CAREFIN Research Papers Series, 14 April.

Rajan R. (2013). A Step in the Dark: Unconventional Monetary Policy after the Crisis. Andrew Crockett Memorial Lecture, BIS, Basel, 23 June.

Santor E. \& Suchanek L. (2016). A New Era of Central Banking: Unconventional Monetary Policies. Bank of Canada Review, Spring, 29-42.

Summers L. (2015). Demand Side Secular Stagnation. American Economic Review, 105(5), 60-65. 